\title{
Preface to Second Edition
}

In preparing this new edition of The Ethics of Deconstruction for Edinburgh University Press, I have added some new material to the original book. The reader will find this material in three appendices: first, 'The Ethics of Deconstruction: An Attempt at Self-Criticism' is the text of a lecture first given at the Institute for Contemporary Arts, London, in July 1992 as part of a discussion session devoted to the book. This text both restates and attempts to clarify the main thrust of my argumentation, taking up certain possible objections to my approach. It first appeared in PLI, Warwick Journal of Philosophy, vol. 6 (Summer 1997), pp. 87-102. Second, 'Habermas and Derrida Get Married' is the hitherto unpublished English version of a text written at the invitation of Axel Honneth, and which explores the question of the possible relation between an ethics of deconstruction and Habermasian discourse ethics as it is presented in connection to Honneth's work on the concept of recognition. It first appeared as 'Habermas und Derrida werden verheiratet', in the Deutsche Zeitschrift für Philosophie, vol. 42, no. 6 (1994), pp. 1025-36. Third, 'Emmanuel Levinas' is the unpublished script of a radio programme commissioned by BBC Radio 3, and first broadcast on 16 January 1998. This short text provides an introduction to what I see as Levinas's central ethical insight which is more in line with my current views. Within the original text, I have restricted myself to minor, but essential, typographical and scholarly corrections.

Since the original publication of The Ethics of Deconstruction, my own views of the themes addressed in the book have been modified and, hopefully, deepened. Crudely stated, these modifications can be reduced to two main points: first, I am more doubtful about the persuasive force of Levinasian ethics in the way it was presented in The Ethics of Deconstruction, which has led me to attempt a critical reconstruction of Levinas's work with particular reference to the 
question of the subject, to Blanchot's interpretation of Levinas, and to Freudian and Lacanian psychoanalysis. Second, based on a reading of Derrida's work since 1992, I am more positive about the political possibilities of deconstruction, specifically insofar as the latter is mediated through a reading of Marx and an account of friendship, democracy and the political decision. The reader can find elaborations of these claims in Ethics - Politics - Subjectivity (Verso, London and New York, 1999), which in many ways is a sequel to this book.

Simon Critchley March 1999 